\title{
European Commission launches consultation on Science 2.0
}

Eurosurveillance editorial team (eurosurveillance@ecdc.europa.eu) ${ }^{1}$

1. European Centre for Disease Prevention and Control (ECDC) Stockholm, Sweden

Citation style for this article:

Eurosurveillance editorial team. European Commission launches consultation on Science 2.o. Euro Surveill. 2014;19(31):pii=20872. Available online: http://www. eurosurveillance.org/ViewArticle.aspx?Articleld=20872

The European Commission has launched a public consultation on 'Science 2.0' which is open until 30 September 2014 [1]. The consultation has three main objectives: (i) to assess the degree of awareness among stakeholders, (ii) assess the perception of opportunities and challenges, and (iii) to identify policy implications and actions to strengthen the competitiveness of the European science and research system [2]. A suggested new approach to science, 'Science 2.0' uses information-sharing and collaboration made possible by network technologies [3].

The 'Science 2.0' consultation paper stresses for example that open access needs to be considered in a broader context and that the dynamics of 'Science 2.0' will further expand open access requirements [2]. The European Commission has made open access to peer-reviewed publications the default position across Horizon 2020, the biggest research and innovation programme ever adopted by the EU [4]. With EUR 80 billion funding from 2014 to 2020 , it is the financial instrument used to implement 'Innovation Union', a cornerstone initiative of Europe 2020, the EU growth strategy which aims to secure the global competitiveness of Europe.

An objective of the European Union (EU) is to strengthen its scientific and technological bases by achieving a European Research Area where researchers, knowledge and technology circulate freely [2]. As part of this, most EU Member States have established legal conditions to support e.g. open access to publications

\section{References}

1. European Commission. Consultation on 'Science 2.0': Science in Transition. [Accessed 7 Aug 2014]. Available from: http://ec.europa.eu/research/consultations/science-2.0/ consultation_en.htm

2. European Commission. Background document. Public consultation. 'Science 2.0': Science in Transition. [Accessed 7 Aug 2014]. Available from: http://ec.europa.eu/research/ consultations/science-2.0/background.pdf

3. Wikipedia. [Accessed 7 Aug 2014]. Available from: http:// en.wikipedia.org/wiki/Science_2.0

4. European Union. What is Horizon 2020 ?. [Accessed 7 Aug 2014]. Available from: http://ec.europa.eu/programmes/ horizon2020/en/what-horizon-2020 